\title{
Industrial Processing of Pickled and Pasteurized Onion (Allium Cepa L.)
}

\author{
Karl Kaack \\ Department of Food Science, University of Aarhus, Aarslev, Denmark
}

\begin{abstract}
Common onion Allium cepa are grown around the world because of their delicious flavour, colour and several health promoting properties. A selection of nineteen field dried onion cultivars were frozen and stored for none, seven, sixty and nineteen days until measurement of the of pyruvic acid that is a measure for pungency and flavour. Onions from 'Hyduro' and 'Hygro' were stored three months at - $25^{\circ}$ until processing of pickled onion using acetic acid only. Field dried onion from nineteen cultivars were peeled carefully, frozen, and analyzed for suitability for processing of pickled onion using acetic acid in order to improve acetic acid as the only supplied ingredient. The aim of this research was thereafter to study the possibilities for industrial processing of pickled onion with attractive sensory properties including flavour, colour, drained weight, texture, flavonoids after blanching, packing and cool storage. That included creation of recipices on the background of foods with pickles presented on the internet and by evaluation of possible ingredients and available processing equipment. Raw stored and frozen onion were evaluated for improvements of quality characteristics regarding peeling, cutting, blanching, packing and sensory properties.
\end{abstract}

Keywords: pickling, cutting, blanching, cooling.

\section{INTRODUCTION}

Raw materials for processing of an untold number of significantly different pickled onions are cultivars from the species (Allium cepa L.) and shallots (Allium ascaloni L.) that in fact are very popular as taste promoters on sandwiches, mixed salads, by hot meals and on breads with preserved fish [1,2, 3]. Onions were selected because of they contribute significantly to odour, colour, and several health promoting compounds including polyphenols, flavonoid antioxidants and antiproliferative compounds, $[1,2]$. Recent research has shown that non-structural carbohydrates produced inside the plant tissue include pyruvic acid, fructose, glucose, sucrose, 1 - kestose, neoketose, nystose, 1F- $\beta$ - D fructofuranosylnystose and three non - completely identified fructans from onions [4]. After harvest, field drying, removal of top and root may the non - peeled onion be stored for at least 40 weeks with a minimum of further losses [5]. Onion bulbs from the allium species are extensively employed as food flavouring and appreciated for their contents of various flavonoids [1, 3]. The high contents of flavonols such as in Tropea ecotype onion may also be associated with positive effects against oxidative damage induced in human erythrocytes [7]. Freeze drying may result in products that retain more of the characteristic flavour components of fresh onion, as judged by sensory tests, than the other processes used by processing of frozen vegetables. Blanching of onion may reduce the contents of aroma compounds significantly because the enzyme alliinase are degraded by heating [8]. Recent research showed microwave heating of onion, cooking without water or frying did not affect frying nor the contents of flavonoids in onion [9]. Frozen storage of peeled onion may result in considerable losses in onion flavour [10]. On this basis it was decided to produce frozen and pickled onion without and with blanching and pasteurization.

\section{MATERIALS AND MethodS}

About $2.5 \mathrm{~kg}$ mature, field dried and size sorted onions were cleaned, peeled by hand, precisely cut into $6 \mathrm{~mm}$ cylindrical rings, that were cut into $4 \mathrm{~mm}$ piecres, blended carefully, placed on a small stainless steel lattice and frozen at $-25^{\circ} \mathrm{C}$ using $\mathrm{CO} 2$ within a few min. The samples were carefully packed into aluminium bags with $100 \mathrm{~g}$ frozen onion pieces and kept closed in a freezer at room at $25^{\circ} \mathrm{C}$ for six months. Preparation of samples for analyses included two times 3 bags of frozen and chorused onion pieces. The first three bags were transferred to 3 times $100 \mathrm{~g}$ water kept at $50{ }^{\circ} \mathrm{C}$ for 30 min and then completely chorused using a high speed blender. The other three samples were trans- 
ferred into water kept at $90^{\circ} \mathrm{C}$ and blended similarly within ten seconds. The differences in the contents of pyruvic acid in two times three bags showed the efficiency of the enzyme alliin lyase. On the basis of these activities it was found that production of pyruvic acid was finished after $30 \mathrm{~min}$. Measurement of released pyruvic acid were carried out using a few g freeze dried onion tissue in $15 \mathrm{~mL}$ glass jars that were supplied with $500 \mu \mathrm{l}$ standard solutions of malic acid, $10 \mathrm{ml}$ methanol, $200 \mu \mathrm{l}$ concentrated sulfuric acid and $500 \mu \mathrm{l}$ boron triflouride. After 20 hours at $20^{\circ} \mathrm{C}$ were the esters of pyruvic and malic acid extracted using $2 \mathrm{~mL}$ solution of pentane and chloroform mixed 1:3. The average contents of the methyl ester of pyruvic acid were measured in six replicates and the retention time for methyl pyruvate and dimethyl malonate were 20.8 and $29.2 \mathrm{~min}$ with three small peaks due to occurrence of acetic acid, malic acid and citric acid, respectively after 43.3, 48.5 and 58.2 min. Separation and quantification of pyruvic acid were carried out using a Hewlett Packard (HP 5840A) gas chromatograph equipped with a $2.5 \mathrm{~m}$ stainless steel column (id 1/8 inch) packed with $5 \%$ polyglycol succinate on $80-100$ mesh diatomite. The extracted compounds were separated by column temperature 50 - $200{ }^{\circ} \mathrm{C}$, with temperature increase $2^{\circ} \mathrm{C} \mathrm{min}^{-1}$ for $0-20 \mathrm{~min}$ and then $4{ }^{\circ} \mathrm{C} \mathrm{min}^{-1}$ up to $200{ }^{\circ} \mathrm{C}$ and 15 min at this temperature. The carrier gas was $7 \mathrm{~mL} \mathrm{~N} 2 \mathrm{~min}^{-1}$ and the standard solution contained $0.5 \mathrm{~g}$ malic acid $100 \mathrm{~g}^{-1}$ (Table 1 ).

\section{RESUltS AND DisCUSSION}

Measurement of pyruvic acid in frozen onions from the four cultivars 'Hygro', 'Huduro', 'Hyblende' and 'Lucrato' using both gas chromatography (GLC) and spectrophotometry (ABS) showed small differences in the contents of pyruvic acid using gaschromatography and spectrometry, respectively (Table 2). These data shows that gas chromatography resulted in a significantly lower values compared to the values obtained using spectrophotometry. The highest and lowest contents of pyruvic acid were found in onions from 'Hygro' and 'Tarzan', respectively (Table 3). It is very important to recognize the signifitive differences in average contents of pyruvic acid between cultivars and especially that the contents of pyruvic acid were reduced 43.8 and 45.5 per cent during frozen storage for 90 days. Another important issue is that residues from processing of fried, frozen and dried onions may be prepared and stabilized by various means and used as specified contents of fibre, alkenyl cysteine sulfoxides, oligosaccharides or odours as suggested previously [11]. Large losses in flavour compounds occurred during cooking, boiling, dehydration and freezing of whole onions or parts of the onion tissues [8]. Assuming use of fresh onion as 100 decreased was freeze dried 45, laboratory frozen 18, hot air dried 9-10, commercially frozen 6-6, boiled 5-2 and pickled 0.01 [8]. Home like peeling and storage have resulted in significantly losses in pyruvate, flavour, flavonoids, anthocyanins and antioxidant activity, whereas freeze-drying resulted in products that retained the characteristic flavour of fresh onion more efficiently [11, 12].

Onions (Allium cepa L.) are consumed worldwide and make an important contribution of sensory properties with antioxidants such as phenolic acids, flavonoids, aroma compounds and anthocyanins [7]. Onion composition varies according to growth conditions, maturity, and storage time for the bulb section and the contents varied significantly between cultivars just as for other vegetables $[1,13,14]$. All the methods of flavour assessment led to the conclusion that these processes were accompanied by large flavour losses. Quantitative estimates of these losses, varied with the analytical method in question, but were in general of the order of 90 to $95 \%$. Odour and taste of onion foods are released by the enzyme alliin lyase (EC 4.4.1.4). The flavonoid distribution in the different layers of the bulbs indicates that the edible part of the onion contains $79 \%$ of the total content of quercetin $4^{6}$-glucoside but only $27 \%$ of the anthocyanins [12]. Storage of onions for 6 weeks in different conditions, all of them mimicking home storage habits, resulted in a decrease to $64-73 \%$ of total anthocyanins, which may be taken into consideration by processing the onions as well as possible [8]. The same trend was verified for the total antioxidant activity, which was reduced to 29-36\%. The edible part of onion contains $76 \%$ of the total of the decrease in glucose and fructose content correlated with anthocyanin degradation was also observed. A unique class of organosulfur compounds forms the primary determinants of onion flavour [8].

Three odourless, non-volatile flavour precursors collectively referred to cysteine sulfoxides are stored in the cytoplasm of intact onions and includes S-propyl cysteine sulfoxide, S-methyl cysteine sulfoxide, and S-(E)-1-propenyl cysteine sulfoxide. The intensity or pungency may be predicted by the differences in the concentrations of these precursors. The enzyme alliinase occur in the compartmentalized the cell's vacuole and is released upon tissue disruption and reacts with these non-volatile precursors. The precursors are cleaved by alliinase to sulfonic acids, ammonia, and pyruvate. The sulfon- 
ic acids are chemically unstable and will combine with another of the same species to give a range of sulphur compounds. Sulfonic acids condense to form thiosulfates that are unstable and undergo dissociation and rearrangement to form primary and secondary volatiles, along with secondary nonvolatile compounds. The balance between pungency and levels of sugars determines the perception of sweetness in an onion [8]. Because of their low pungency, mild onions are primarily eaten raw and are added to foods including, salads, sandwiches, dips, dressings and cold side dishes. Full-flavored pungent onions possess a higher concentration of sulphur-based compounds that improve the perception of sweetness. The content of pyruvic acid decreased during storage of onion from the cultivar 'Hyduro' at $-25^{\circ} \mathrm{C}$ decreased according to linear equations using gas chromatography and spectrophotometry (Table 2) and the common decrease rate could be measured using an linear equation: pyruvic acid $=57-0.24$ days; $R=0.97$ ). A large number of aroma compounds in onion are produced from $S$ substituded L-cysteine sulfoxide derivatives by the enzyme alliinase resulting in characteristically onion odour compounds including gamma sitosterol, ergos8-en-3ol, cholesta-4,6-dien-3-ol, cholesterol, humulene, myristic acid, fucosterol and several organic acids [9]. In about 10 days after the last normal picking time have the onions reached maximum weight and the contents of dry matter were kept almost even [5]. At a certain stage of maturation may the composition of onion be in balance regarding contents of flavonoids $[3,6,7,12]$. The contents of dry matter in raw non-peeled onions de-

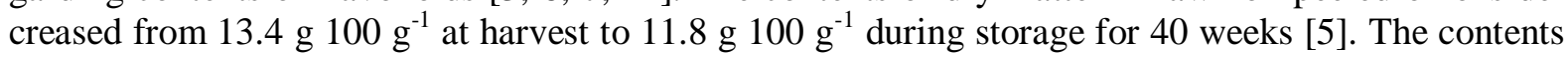
of fructose, and sucrose increased, whereas the contents of glucose and fructans decreased significantly during the storage period. Besides occurred significantly differences in the composition of the outer, middle and inner most onion leaves [8]. During storage of raw non-peeled onion decreased the fresh weight of 10 onions from 186 to $118 \mathrm{~g} \mathrm{~kg}^{-1}$ [5]. Home like storage, peeling and cooking did not result in significantly increases in the contents of the health promoting foods and optimum storage and processing did not result in the most valuable foods [12]. Anthocyanin like foods is not always satisfactory because it may result in significantly losses of flavonoids and carbohydrates as shown by microwave cooking without water, that not reduced the contents of flavonoids and frying does not always affect positively [12]. The pink colour of onion is a complex mixture of highly conjugated species composed of two N-substituted 3.4-dimethylpyrrole-derived rings linked by either a methine or a propylene bridge that may be modified by various $\mathrm{C} 1$ - and $\mathrm{C} 2$ - side chains [11]. Processing of pickled onion pieces by blanching for $0,1,2$ and 4 min combined with pasteurization at 70, 75, 80, 85 and $90^{\circ} \mathrm{C}$ did not have any clear significant effect on drained weight except the significantly low figures (Table 4). Increasing blanching time from 1 to 4 min resulted in significantly decreases in firmness from $500 \mathrm{~kg}$ to $436 \mathrm{~kg}$ by blanching for $4 \mathrm{~min}$ at $70^{\circ} \mathrm{C}$ and to $95 \mathrm{~kg}$ by blanching for $4 \mathrm{~min}$ at $90^{\circ}$ (Table 4). Besides were the pickles red brownish at all pasteurizing temperatures without blanching and by blanching for $1 \mathrm{~min}$ at $80^{\circ} \mathrm{C}$. Blanching for 2 and $4 \mathrm{~min}$ at $80^{\circ} \mathrm{C}$ and 1 to $4 \mathrm{~min}$ at 85 and $95^{\circ} \mathrm{C}$ had all pickles an attractive yellow colour, which may be due to occurrence of xanthophyll's and increasing blanching time by resulted in whereas increasing pasteurization temperature caused increasing firmness at blanching time 0 and decreasing firmness by increases in blanching time for 1,2 and 4 min and decreasing firmness by blanching for 1, 2 and $3 \mathrm{~min}$. Without both blanching and firmness caused increased significantly with increasing important for drained weights non-blanching from 70 to 90 and pasteurized onion from the cultivar 'Hygro' in glass jars and blanched for 2 min at $80^{\circ} \mathrm{C}$ did not have red-brown spots but a light yellow colour in the outer onion rings (Table 4). Blanching at 85 and $90{ }^{\circ} \mathrm{C}$ resulted in yellow colours if the blanching time were minimum 1 min by blanching at 85 and $90^{\circ} \mathrm{C}$ (Table 4). However, these temperatures may result in significant softening of the onions which may result in a non-satisfactory texture (Table 4). Non-blanched samples of pickled onion had a non-satisfactory brown and red colour after storage for 2 months at $20{ }^{\circ} \mathrm{C}$. Processing of pickled onion included use of brine with $0,30,60,120,300,400 \mathrm{mg} 1000 \mathrm{~cm} 3$ ascorbic acid. However, all samples had a non-satisfactory colour without significant effects of ascorbic acid on the browning.

Results from blanching of pickled onions for $0,1,2$ and $4 \mathrm{~min}$ in combination with pasteurization at $70,75,80,85$ and $90^{\circ} \mathrm{C}$ min showed that blanching temperature and time had none or a minimally effects on drained weight (Table 5). Firmness increased significantly by increasing blanching temperature from 70 to $90{ }^{\circ} \mathrm{C}$ by blanching time zero. Blanching at $70{ }^{\circ} \mathrm{C}$ resulted in maximum of firmness at blanching times 1 and $2 \mathrm{~min}$ and a minimum by blanching time $4 \mathrm{~min}$. Blanching at 70 to $90^{\circ} \mathrm{C}$ for 1 to 4 min resulted in significantly decreasing firmness (Table 4). Onion processed by blanching using $0,1,2,4 \mathrm{~min}$ at 70 and $75^{\circ} \mathrm{C}$, and $1 \mathrm{~min}$ at $80^{\circ} \mathrm{C}$ had the colour of blanched onions from the cultivar 'Hygro' a heavy red brown surface colour. Blanching for 2 and 4 min at $80^{\circ} \mathrm{C}$, and 1,2 and 4 min at 90 and $95^{\circ} \mathrm{C}$ resulted in a very nice yellow colour that may be due to xanthophylls as found in onion 
previously (Table 4). The yellow colour belongs to the two tristimulus yellowness (b) and greenness (-a) with a characteristic colour as yellow green 'Golden Delicious' in the early maturation phase of 'Golden Delicious' apple. The data in table 5 shows that blanching for $0,1,2,4 \mathrm{~min}$ at $70-80^{\circ} \mathrm{C}$ had none significantly effect on drained weight, while firmness decreased significantly by these treatments. The colour of these onions varied in colour from red brown (rb) by blanching at $70-75{ }^{\circ} \mathrm{C}$ and a yellow colour (y) by blanching for 2 to 4 min at higher temperatures (Table 5). Development of various peeled and processed onions seem to be due to formation of highly conjugated molecules composed of two $\mathrm{N}$-substituted 3,4-dimethylpyrrole derived rings linked by a methine or a propenylidine bridge [11]. Data from pasteurization of pickled onion processed from the cultivars 'Hygro' and 'Hyduro' for 0 to 25 min showed that firmness increased weekly with a maximum by pasteurization for $10 \mathrm{~min}$ whereas drained weight ceased significantly during pasteurization for $25 \mathrm{~min}$ (Table 4). Both drained weight and firmness decreased significantly by increasing blanching time at increasing temperatures. The red brown colour could be degradation products from the flavonoid quercetin (quercetin 2-(3, 4-dihydroxyphenyl)-3, 5, 7-trihydroxy-4H-chromen-4-one) that also appear in greenish white and light yellow colours of the onion leaves [17]. Firmness of onion from 'Hygro' and 'Hyduro' decreased and greenness increased significantly by increases in the blanching temperature and time from $01 \mathrm{~min}$. By blanching at 0 and $1{ }^{\circ} \mathrm{C}$ for none to $25 \mathrm{~min}$ occurred significantly decreases in firmness and increases in greenness by processing of onions (Table 4). In both series with blanching was the firmness higher for 'Hygro' in comparison to the changes for the cultivar 'Hydro'. The increases in greenness without blanching varied from - 0.3 to 5.1. The colour was satisfied by blanching at $85^{\circ} \mathrm{C}$ and $90^{\circ} \mathrm{C}$. Occurrence of pink discoloration of onion seemed to include 15 major colour compounds in a complex mixture of conjugated species composed of two N-substituted 3,4dimethylpyrrole-derived rings linked by either a methine or a propenylidine bridge and they may be further modified by various C1- and C3-side chains [11]. The surface colour found in this experiment may in the first hand be an example of positive discolouration developed as described previously [11]. Another example of the effects of blanching shows how the greenness may occur by blanching of the two cultivars 'Hygro' and 'Hyduro' that are being green both without blanching and by blanching for one minute (Table 5). In total, structures of several major colour compounds were tentatively determined. It was found that the pigment is a complex mixture of highly conjugated species composed of two N-substituted 3,4-dimethylpyrrole-derived rings linked by either a methine or a propenylidine bridge. These two-ring units are further modified by various $\mathrm{C} 1$ - and $\mathrm{C} 3$-side chains. Experiments with isotope labelled thiolsulphinate revealed that the methine-bridge and $\mathrm{C} 1$-side chains originate from the methyl group of methine, whereas the $\mathrm{C} 3$ units are derived from the propenyl group of iso alliin. Data from blanching of onion pieces at $90^{\circ} \mathrm{C}$ for 0,1 and 2 min showed that absorbance decreased significantly from 0.076 to a minimum at $490 \mathrm{~nm}$ and increased thereafter to a maximum at $530 \mathrm{~nm}$ and then decreased absorbance to none at $664 \mathrm{~nm}$ according to asymptotic equation that corresponds with anthocyanins in various red onion cultivars. Samples blanched for 1, 2 and 4 min did not show any similar peak. It was therefore concluded that these changes in absorbance may be due to occurrence of parts of anthocyanins that are degraded during blanching. Pickled onions were processed using raw materials from the cultivar 'Hygro' as by processing frozen onions. Processing of pickled onion pieces included peeling of $150 \mathrm{~g}$ onion pieces in $370 \mathrm{~mL}$ glass jars and supplied with

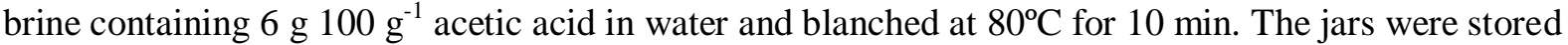
at $20^{\circ} \mathrm{C}$ for two months. Blanching were carried out in water baths with $35 \mathrm{~L}$ water at the stipulated temperature and cooled in tap water at $12^{\circ} \mathrm{C}$. The blanching experiments included three series of blanching at $70,75,80,85^{\circ} \mathrm{C}$ for $0,1,2,4 \mathrm{~min}$. Pasteurization was carried out using blanched of onion pieces for $1 \mathrm{~min}$ at $85{ }^{\circ} \mathrm{C}$ and pasteurized for $0,5,10,15$ and $25 \mathrm{~min}$ at $85^{\circ} \mathrm{C}$. The heat processing of onion pieces was estimated using glass jar dimensions volume $\mathrm{V}$, height $\mathrm{h}$, diameter and $\mathrm{f}=1 \mathrm{slope}^{-1}$, thermal diffusivity $\alpha=\mathrm{cm} 2 \mathrm{~min}^{-1}$, slope $1 \mathrm{~min}^{-1}$, thermal diffusivity $\alpha=\mathrm{cm} 2 \mathrm{~min}^{-1}$, heat transfer $\mathrm{cal}^{-1} \mathrm{~min}^{-1}$. Cultivars and consumption typologies of the Allium species under study show significantly differences in the flavonol contents, from the very low quantity of antioxidant compounds in white onion, about $7 \mathrm{mg} / \mathrm{kg}$ against $600-700 \mathrm{mg} / \mathrm{kg}$ that were found in red and gold varieties, to the enormous content of flavonols that are present in onions of prompt consumption, where quercetin $4^{\prime}$ glucoside exceeds $1 \mathrm{~g} \mathrm{~kg}^{-1}$ and quercetin 3-glucoside is present in a ratio higher then 10:1 with respect to its value in the other onion typologies. Shallots are very rich in the two major flavonols. The effects of cultivar, field drying, cool storage, peeling method, and mechanical damage on dry matter, glucose, fructose, 1 - kestose, neokestose, nystose and $1 \mathrm{~F}-\beta$ - D - fructo-furanosyl-nystose and four nonidentified compounds have been discussed previously $[4,5]$. These data include knowledge about op- 
timal cool stage of raw onion in order to be able to promote human health using foods with a high content of flavonoids that promote human erythrocyte oxidative stress [7]. These changes occur immediately by mechanical damage of the onion tissue and completely by mechanical separation of the onion tissue [12]. These reactions are finished in very short time and the amount of pyruvic acid may be used as a measure of flavour production because pyruvic acid appears because of enzymatically disintegrated comminution. More than 95 per cent of the maximum amount of pyruvic acid is produced within 6 minutes after the start of comminution. The total amount produced appeared to depend on the generally accepted degree of pungency of the onion lot investigated. Øverst på formularen Nederst på formularen Gas chromatographic determination of the volatiles from fresh "Sunspice" onions revealed that the principal disulphide present is n-propyl allyl, methyl-n-propyl, methyl allyl, dimethyl, and diallyl. In dehydrated onions this order is markedly altered. Quantitative estimates of the disulphide content of 53 lots of fresh onions were made and compared with analyses of dehydrated onions from comparable lot numbers. Loss of measured volatiles averaged $98 \%$, while the losses of disulphides were greater than $89 \%$. Cultivars and consumption typologies of some Allium species can significantly vary from a chemical point of view and even small differences can be important for their characterization and differentiation [6]. Bulbs of three varieties and four consumption typologies of onion (Allium cepa L.) and two varieties of shallot (Allium ascalonicum Hort.) were subjected separated by high pressure liquid gas chromatography. Seven flavonol glucosides were identified in all the samples, two of which, quercetin 3, 4'-diglucoside and quercetin 4'-glucoside, represent about the $90 \%$ of the overall contents. Cultivars and consumption typologies of the Allium species under study show significant differences in flavonols contents, from the very low quantity of antioxidant compounds in white onion, about $7 \mathrm{mg} / \mathrm{kg}$ against $600-700 \mathrm{mg} \mathrm{kg}^{-1}$ that were found in the red and gold varieties, to the enormous content of flavonols that are present in onions from prompt consumption, where quercetin 4'-glucoside exceeds $1 \mathrm{~g} \mathrm{~kg}^{-1}$ and quercetin 3-glucoside is present in a ratio higher then 10:1 with respect to its value in the other onion typologies. Shallots are very rich in the two major flavonoids studied were quercetin and kaempferol. The contents of quercetin and kaempferol have been measured in relation to the effect of different heat treatments. The identification and quantification of the flavonoids were performed with high performance liquid chromatography using UV detection. The greatest loss of flavonoids in onion took place during the pre-processing step where the onion was peeled, trimmed, and chopped before blanching. Blanched onion contained $25 \mathrm{mg}$ quercetin and $0.35 \mathrm{mg}$ kaempferol per $100 \mathrm{~g}$ edible part. Further cooking, frying or warm-holding for up to 2 $\mathrm{h}$ of the blanched vegetables, did not influence the flavonoid content. Onions in ready-made dishes and home-cooked food may be good dietary sources of flavonoids. The contents of flavonoids in onions, green beans, and peas have been analysed in relation to the effect of different heat treatments. Two major flavonoids were found, quercetin and kaempferol. The identification and quantification of the flavonoids were performed with high performance liquid chromatography and UV detection. The greatest loss of flavonoids in onion took place during the pre-processing step where the onion was peeled, trimmed, and chopped before blanching. Blanched onion contained $25 \mathrm{mg}$ quercetin and 0.35 mg kaempferol per $100 \mathrm{~g}$ edible part. Further cooking, frying or warm-holding for up to $2 \mathrm{~h}$ of the blanched vegetables, did not influence the flavonoid content. Recent analysis showed that the dry matter in onion (11.7 g $100 \mathrm{~g}$-1) are composed of glucose, fructose, sucrose, 1-kestose, neo-kestose, nystose and $1 \mathrm{~F}-\beta-\mathrm{D}-\beta$-fructofyranosylsystose and four unknown compounds that varied significantly between six cultivars [4]. Odour and taste of onion foods are released by the enzyme alliin lyase (EC 4.4.1.4) and previous research have shown that the onion has a high capacity in formation of pyruvic acid from a diversity of organic compounds [5]. Measurement of pyruvic acid in frozen onion were carried our using two analytical methods based on gas chromatography and spectrometry did not result in any significantly differences except for measurement at the first day of storage, where gas chromatography resulted in a significantly lower value in comparison to value obtained using a spectrophotometric method and shows that the contents decreased significantly with the length of storage time according to linear equations (Table 1).

Studies in the effects of industrial processing on the contents of onion flavour components showed occurrence of a considerable loss of flavour compounds by industrial processing such as boiling, dehydration and freezing showed that mainly was due to complete and partial destruction of enzymes and precursors $[8,13]$. Blanching of pickled onions in water at $70-85^{\circ} \mathrm{C}$ did not affect drained weight significantly, whereas blanching for 1,2 and 4 min resulted in disappearance of the red-brown colour by blanching at $85-90^{\circ} \mathrm{C}$ for $1 \mathrm{~min}$ and at $80-90{ }^{\circ} \mathrm{C}$ for $2-4 \mathrm{~min}$, respectively (Table 2). This colourant were named yellow/green because this colour corresponds to the area with mixtures in the green and 
yellow of the tristimulus values were these colours are mixed. Previous research have shown that quercetin and its derivatives impart red and purple flavonols such as quercetin that may cause yellow and brown compounds in the skin of many varieties [14]. Firmness of the blanched onions decreased significantly with increasing temperature and blanching time (Table 2). These data shows that pickled onion pieces have a texture that may be recognized by the consumers and that several characteristic textures may be obtained according to various heat treatments. The effect of the following processes on the flavour of the product as compared with that of fresh onion has been investigated: pickling, canning, boiling and frying under domestic conditions, dehydration in hot air and by freeze-drying and freezing. Flavour assessments were based on determination of pyruvate, thiolsulphinate and volatile components in headspace, gas-liquid chromatograms as well as sensory testing in certain cases. All the methods of flavour assessment led to the conclusion that these processes were accompanied by large flavour losses. Quantitative estimates of the losses, varied with the analytical method in question, but were in general of the order of 90 to $95 \%$ [8]. Freeze-drying gave a product which retained more of the characteristic flavour components of fresh onion, as judged by sensory tests, than the other processes and in this case the taste threshold test indicated a flavour loss of $95 \%$, pyruvate a loss of $25 \%$, thiolsulphinate $26 \%$ loss and gas-liquid chromatography a loss of total peak area of $57 \%$. Evidence that onions are consumed mainly for their flavour rather than as a source of nutrients in the classical nutritional sense is discussed and other factors which influence the flavour strength of the vegetable are reviewed. The average firmness during pasteurization decreased according to linear equation: $\mathrm{kg}=419-6.29(\mathrm{R}=0.96)$. The effect of the following processes on the flavour of the product as compared with that of fresh onion has been investigated: pickling, canning, boiling and frying under domestic conditions, dehydration in hot air and by freeze-drying and freezing. Flavour assessments were based on determination of pyruvate, thiolsulphinate and volatile components in headspace, gas-liquid chromatograms as well as sensory testing in certain cases. All the methods of flavour assessment led to the conclusion that these processes were accompanied by large flavour losses.

Quantitative estimates of the losses, varied with the analytical method in question, but were in general of the order of 90 to $95 \%$. Freeze-drying gave a product which retained more of the characteristic flavour components of fresh onion, as judged by sensory tests, than the other processes and in this case the taste threshold test indicated a flavour loss of $95 \%$, pyruvate (P) a loss of $25 \%$, thiolsulphinate $26 \%$ loss and gas-liquid chromatography a loss of total peak area of $57 \%$. Evidence that onions are consumed mainly for their flavour rather than as a source of nutrients in the classical nutritional sense is discussed and other factors which influence the flavour strength of the vegetable are reviewed Pyruvic acid appears enzymatically in onion tissue disintegrated by comminution. Over $95 \%$ of the maximum amount of pyruvic acid is produced within 6 minutes after the start of comminution. The total amount produced appeared to depend on the generally accepted degree of pungency of the onion lot investigated. Weak onions produced 2 to $4 \mu$ moles, those of intermediate strength 8 to $10 \mu$ moles, and strong onions 15 to $20 \mu$ moles of pyruvic acid per gram of onion. The enzymatic basis of the method, as well as its relation to other methods of estimation of pungency, is discussed [8, 12].

Without blanching increased drained weight of onion pieces significantly from 154 to $167 \mathrm{~g}$, while firmness decreased significantly from 453 to $159 \mathrm{~kg}$ and the red brown colour disappeared by blanching for 0 and $5 \mathrm{~min}$ and a yellow/green colour occurred by blanching time from 10 to $25 \mathrm{~min}$ (Table 3). Blanching for 5-25 min did not affect drained weight, whereas firmness decreased significantly by blanching for 5 to $25 \mathrm{~min}$ (Table 3). Anthocyanin and cyanidin derivatives constitute $50 \%$ of total anthocyanins, but delphinine and petunidine derivatives, which have not been reported in red onions thus far, were also detected. The flavonoid distribution in the different layers of the bulbs indicates that, after homelike peeling, the edible portion contained $79 \%$ of the total content of quercetin $4^{4}-$ glucoside but only $27 \%$ of the anthocyanins. Storage of onions for 6 weeks in different conditions, all of them mimicking home storage habits, resulted in a decrease to $64-73 \%$ of total anthocyanins. The same trend was verified for the total antioxidant activity, which was reduced to $29-36 \%$. A decrease in glucose and fructose content correlated with anthocyanin degradation was also observed. Yellow onions contain 270-1187 mg kg-1 fresh onion flavonoids, and red onion containing 415-1917 $\mathrm{mg} \mathrm{kg}^{-1}$ flavonoids [3]. As compared with fresh onion as 100, enzyme activities of the processed products were freeze dried 45 , laboratory frozen 18 , hot air dried 8.8-10.0, commercially frozen 6.6 , boiled 5.2 and pickled 0.01 [8]. The data in table 4 showed significantly decreases in firmness with blanching and with increasing blanching times for onion pieces (Table 4). All the methods of flavour assessment led to the conclusion that these processes were accompanied by large flavour losses. Quantitative estimates of the losses, varied with the analytical method in question, but were in general of the order of 
90 to $95 \%$. Freeze-drying gave a product which retained more of the characteristic flavour components of fresh onion, as judged by sensory tests, than the other processes and in this case the taste threshold test indicated a flavour loss of $95 \%$, pyruvate $(\mathrm{P})$ a loss of $25 \%$, thiolsulphinate $26 \%$ loss and gas-liquid chromatography a loss of total peak area of $57 \%$. Evidence that onions are consumed mainly for their flavour rather than as a source of nutrients in the classical nutritional sense is discussed and other factors which influence the flavour strength of the vegetable are reviewed. a Department of Analytical Chemistry, Food Science and Nutrition, University of La Laguna, Avda. Astrofísico Francisco Sánchez s/n, 38201 La Laguna, Santa Cruz de Tenerife, Spain b Agricultural by Biodiversity Conservation Center of Tenerife, Exmo. Cabildo Insular de Tenerife, Ctra. TacoronteTejina no. 20-A, 38350 Tacoronte, Santa Cruz de Tenerife, Spain Received 22 May 2007, Revised 29 May 2008, Accepted 3 July 2008, Available online 22 August 2008.

The effects of cultivar, field drying, cool storage, peeling method, and mechanical damage on dry matter, glucose, fructose, 1-kestose, neokestose, nystose and $1 \mathrm{~F}-\beta-\mathrm{D}$ - fructo-furanosyl-nystose and four non-identified compounds have been discussed previously $[4,5]$. These changes occur immediately by mechanical damage of the onion tissue and completely by mechanical separation of the onion tissue [12]. These reactions are finished in very short time and the amount of pyruvic acid may be used as a measure of flavour production because pyruvic acid appears because of enzymatically disintegrated comminution. More than 95 per cent of the maximum amount of pyruvic acid is produced within 6 minutes after the start of comminution. The total amount produced appeared to depend on the generally accepted degree of pungency of the onion lot investigated. Øverst på formularen

Nederst på formularen Gas chromatographic determination of the volatiles from fresh onions revealed that the principal disulphide present is followed in descending, order of concentration by n-propyl allyl, methyl-n-propyl, methyl - allyl. Quantitative estimates of the disulphide content of 53 lots of fresh onions were made and compared with analyses of dehydrated onions from comparable lot numbers. Loss of measured volatiles averaged $98 \%$, while loss of disulfides was greater than $89 \%$. The relationship of disulphides to onion flavour and a pungency ranking system based on these analyses are discussed [20]. Storage of onions for 6 weeks in different conditions, all of them mimicking home storage habits, resulted in a decrease to $64-73 \%$ of total anthocyanins. The same trend was verified for the total antioxidant activity, which was reduced to $29-36 \%$. The moisture, ash, protein, Brix degree, glucose, fructose, sucrose, total fructans and total sugar, total and insoluble fibre contents were quantified in five traditional onion cultivars from Tenerife Guayonje, San Juan de la Rambla, Carrizal Alto, Carrizal Bajo and Masca) and a commercial cultivar. Processing by pickling, canning, boiling and frying under domestic conditions, dehydration in hot air and by freeze-drying and freezing resulted in significantly losses. The use of synthetic ( \pm ) - S - 1- propyl - L- cysteine sulphoxide and of alliinase preparations in studies of flavour changes resulting from processing of onion (Allium cepa L.) and shown to include: (a) complete or partial enzyme destruction; (b) partial non-enzymic destruction of precursors; and (c) partial enzymatic hydrolysis of precursors with loss of volatile reaction products. A stable, freeze-dried alliinase preparation and synthetic $( \pm)$ - S 1- propyl L cysteine sulphoxide $(( \pm)$ PCSO) were prepared by known methods. Addition of an excess of enzyme to the processed product under optimal conditions was used in the determination of residual native substrate in the processed products and of an excess of the synthetic substrate for assay of enzymic activity. As compared with fresh onion as 100, enzymic activities of the processed products were as follows: freeze-dried 45, laboratory-frozen 18, hot-air dried 8.8-10, commercially-frozen 6.6, boiled 5.2 and pickled 0.01 . Non-enzymic destruction of substrate (precursor) was greatest in the hot-air dried product (ca 80\%) and least in freeze-dried onion (2.0\%). Model experiments based on the alliinase preparation, ( \pm )-PCSO and cis-S-1-propenyl-L-cysteine sulphoxide (the major component of the native onion precursors is the trans-isomer) exaggerated destruction of enzyme at 60 and $100{ }^{\circ} \mathrm{C}$ as compared with the relevant processed products, yet underestimated the substrate losses at these temperatures. It was concluded that factors other than those embodied in the model conditions were also involved. The effect of the following processes on the flavour of the product as compared with that of fresh onion has been investigated: pickling, canning, boiling and frying under domestic conditions, dehydration in hot air and by freeze-drying and freezing. Flavour assessments were based on determination of pyruvate, thiolsulphinate and volatile components in headspace, gas-liquid chromatograms as well as sensory testing in certain cases. All the methods of flavour assessment led to the conclusion that these processes were accompanied by large flavour losses. Quantitative estimates of the losses, varied with the analytical method in question, but were in general of the order of 90 to $95 \%$. Freeze- 
drying gave a product which retained more of the characteristic flavour components of fresh onion, as judged by sensory tests, than the other processes and in this case the taste threshold test indicated a flavour loss of $95 \%$, pyruvate (PE) a loss of $25 \%$, thiolsulphinate $26 \%$ loss and gas-liquid chromatography a loss of total peak area of $57 \%$. Evidence that onions are consumed mainly for their flavour rather than as a source of nutrients in the classical nutritional sense is discussed and other factors which influence the flavour strength of the vegetable are reviewed. Data regarding the effects of blanching on drained weight of pickled onion shown in table 4 does not show any particular differences except blanching for $1 \mathrm{~min}$ at $80^{\circ} \mathrm{C}, 2 \mathrm{~min}$ at $70^{\circ} \mathrm{C}$ and $4 \mathrm{~min}$ at $75^{\circ} \mathrm{C}$ that resulted in the significantly lowest values of drained weight (Table 4). Without blanching were firmness medium at $70^{\circ} \mathrm{C}$, minimum at $75^{\circ} \mathrm{C}$ and increased thereafter by blanching up to $90^{\circ} \mathrm{C}$ (Table 4). By blanching at $70^{\circ} \mathrm{C}$ and $75^{\circ} \mathrm{C}$ for $1 \mathrm{~min}$ were firmness at maximum and decreased thereafter significantly up to blanching at $90{ }^{\circ} \mathrm{C}$. Blanching for 2 and $4 \mathrm{~min}$ resulted in decreasing firmness by significantly increasing temperatures (Table 4). The colour of pickled onion were reddish brown by all temperatures without blanching, by blanching for 1,2 and $4 \mathrm{~min}$ at 70 and $75^{\circ} \mathrm{C}$ and $1 \mathrm{~min}$ at $80^{\circ} \mathrm{C}$. The colour were yellow/green by blanching at $80{ }^{\circ} \mathrm{C}$ for 2 and $4 \mathrm{~min}$ and by $1,2,4 \mathrm{~min}$ at 85 and $85^{\circ} \mathrm{C}$ (Table 4). Firmness decreased significantly by increasing pasteurization for 0 to $25 \mathrm{~min}$ for both blanching times and was significantly lowest for onions from 'Hyduro' onions in comparison to 'Hygro' onions (Table 5). Greenness increased by increasing blanching time for both cultivars and was highest for 'Hyduro' onions. Data from determination of the effects of blanching time 0 and $1 \mathrm{~min}$ and pasteurization time 0 to $25 \mathrm{~min}$ on drained weight and firmness and colour of pickled onion showed that pasteurization time not affected drained weight significantly, whereas firmness decreased significantly by increasing pasteurization time (Table 7). The colour of pickled onion had a red brownish colour without blanching time for 0 and 1 min resulted in red brownish colour without blanching after pasteurization for 0 to 5 min without blanching and red brownish without blanching for $1 \mathrm{~min}$ (Table 7). Data from determination of the heating rate in table 11 shows the variations in processing of pickled onion in five size glass jars with volumes from 370 to $1100 \mathrm{~cm}^{3}$. The height and diameter of the jars varied from 370 to $1100 \mathrm{~cm}^{3}$ corresponding to the volumes shows the effects of variations in height and diameter. The termal diffusivity $\mathrm{cm} 2 \mathrm{~min}^{-1}$ varied $\mathrm{m}$ significantly in correspondence with the heath transfer and the time to center temperature increased $3.1 \mathrm{~min}$ by increasing jar size. (Table 12). On the basis of these data it is still obvious to use equal volumes on equal size by evaluation of treatment effects.

The precursor of the orange-red pigment formed upon wounding the bulbs of Allium giganteum (Allium subg. Melanocrommyum) was isolated and shown to be S-(2-pyrrolyl)cysteine S-oxide. In addition, two other pyrrolylsulfinyl derivatives were found in an extract from the bulbs, namely, 3-(2pyrrolylsulfinyl)lactic acid and S-(3-pyrrolyl)cysteine S-oxide. Contrary to a previous report, the latter compound was shown not to serve as the precursor of the pigment, being in fact only an artifact formed during isolation. The formation of pyrrolyl-containing compounds following disruption of $\mathrm{A}$. giganteum bulbs was studied by a combination of LC-MS, LC-NMR and DART-MS. It was found that $\mathrm{S}$-(2-pyrrolyl)cysteine $\mathrm{S}$-oxide is cleaved by a $\mathrm{C}-\mathrm{S}$ lyase (alliinase) to yield 2-pyrrolesulfenic acid. Two molecules of the latter compound give rise to highly reactive S-(2-pyrrolyl) 2pyrrolethiosulfinate which in turn converts into red 2,2'-epidithio-3,3'-dipyrrole (dipyrrolo[2,3-d:2',3'e]-1,2-dithiin). Several other pyrrolyl-containing compounds were detected in A. giganteum for the first time, including S-methyl 2-pyrrolethiosulfinate, S-(2-pyrrolyl) methanethiosulfinate, di(2pyrrolyl) disulfide, and S-(2-pyrrolyl) 2-pyrrolethiosulfonate. It can be concluded that the formation of the orange-red pigment in Allium subg. Melanocrommyum species, despite sharing several analogous features, is of a different nature than the pink discoloration of onion (A. cepa).

\section{REFERENCES}

[1] Yang, J. Meyers, J. van der Heide, R. Liu, H. 2004. Varietal differences in phenolic content and anti- proliferative activities of onions J. Agric. Food Chem. 52, 6787-6793.

[2] Lachman, J., Proněk, D., Hejtmánková, A., Dudjak, J., Pivec., V., Faitová, K. 2003. Total polyphenol and main flavonoid antioxidants in different onion (Allium cepa L.). Hort. Sci. (Prague), $30,142-147$.

[3] Slimestad, R., Fossen, T., Vågen IM. 2007. Onions: A source of unique dietary flavonoids. J. Agric. Food Chem. 55, 10067-10080.

[4] 4. Kaack, K., Christensen, L.P., Hansen, S. L., Grevsen, K. 2004. Non-structural carbohydrates in processed soft fried onion (Allium cepa L.). Eur. Food Res. Technol. 218, 372-379. 
[5] Hansen, S. L. 1999. Content and composition of dry matter in onion (Allium cepa L.) as influenced by developmental stage at time of harvest and long-term storage. Acta Agric. Scand., Sect. B. Soil and Plant Sci. 49, 103-109).

[6] Bonaccorsi, P., Corrado C., Gargiulli, C. 2008. Flavonol glucosides in Allium species: A comparative study by means of HPLC-DAD-ESI-MS-MS. Food Chem. 107,1668-1673.

[7] Tedesco, I.., Carbone, V., Spagnuolo, C., Minasi, P., Russo, G.L. 2015. Identification and quantification of flavonoids from two southern Italian cultivars of Allium cepa L., Tropea (Red onion) and Montor (Copper onion) and their capacity to protect human erythrocyte oxidative stress. J. Agric. Food Chem. 63, 5229-5238.

[8] Freeman, G. G., Whenham, R. J. 1975. Changes in onion (Allium cepa L.) Flavour components resulting from some post-harvest processes Volume 25, Pages 499-515.

[9] Ioku, K., Aoyama, Y., Tokuno, A., Terao, J., Nakatani, N., Takei, Y. 2001. Various cooking methods and the flavonoid content in onion. J. Nutr Sct. Vitaminol, 47, 78-83.

[10] Kaack, K. 1988. Changes in pyruvic acid formation in frozen onion. Danish J. Plant and Soil Science 92, 275-278.

[11] Kubec, R. Velisek, J. 2015. Distribution of S-Alkenylcysteine Sulfoxides in Some Allium Species. Identification of a New Flavour Precursor: S-Ethylcysteine Sulfoxide (ethiin). J. Agric. Food Chem. 48, 428-433.

[12] Gennaro, L., Lombardi, C., Esposito, F., Salkucci, M., Maianni, G., Quaglia, G., Fogliano, V. 2002. Flavonoid and carbohydrate contents in Tropea Red Onions: Effects of homelike peeling and storage. J. Agric. Food Chem. 50, 1904-1910.

[13] Anthon, GE, Barrett D.M 83, J. (2003). Modified method for determination of pyruvic acid with dinitrophenyl hydrazine in the assessment of onion pungency. J Sci. Food Agric. 83, 1210-1213.

[14] Downess, K., Chope, G.A. Terry, L. A. 2009.) Effect of curing at different temperatures on biochemical composition of onion (Allium cepa L.) skin from three freshly cured and cold stored UK-grown.onion. Postharvest Biology and Technology 54, 80-86.

[15] Kubec, R., Urajová P., Lacina O., Hajšlová J, Kuzma M., Zápal J. 2015. Allium discoloration: color compounds formed during pinking of onion and leek. J. Agric. Food Chem. 63, 1019210199.

[16] Schwimmer, S, and Weston W. J. J. 1961b. Enzymic development of pyruvic acid in onion as a measure of pungency. J. Agric. Food Chem. 9, 301-304.

[17] Mogren L., Geertson U., Olsson M. E. 2008. Effect of cultivation factors on flavonoid content in yellow onion (Allium cepa L.). Acta Hort. 765, 191-195.

[18] Kubec R. Svobodováj M. Velíšek J. Agric. Food Chem. 2000, 48, 428-433. Kubec R., Urajová, P., Hajšlová, J., Kuzma, M., Zápal J. 2015. Allium Discoloration: colour compounds formed during pinking of onion and Leek. J. Agric. Food Chem., 2015, 63 (46).

[19] Schwimmer S., Weston, W. J. 1961a. Onion flavour and odour, enzymatic development of pyruvic acid in onion as a measure of pungency. J. Agric. Food Chem. 9, 301-304.

[20] Schwimmer S., Weston, W. J. 1967. Cysteine induced odour intensification in onion and other foods. J. Agric Food Chem. 9, 301-304.

[21] Kubec, R, Svobodavá, M., Velisek, J. 2000. Distribution of S-Alk(en)ylcysteine sulfoxides in some Allium Species. Identification of a New Flavor Precursor: S-Ethylcysteine Sulfoxide (Ethiin). J. Agric Food Chem J. Agric. Food Chem. 2000, 48, 428-433.

[22] Leonardi, C., Esposito F, Salucci M., Maiani, G., Quaglia G, Fogliano, V. 2002, Flavonoid and carbohydrate contents in Tropea Red Onions: Effects of homelike peeling and storage. J. Agric. Food Chem. 50, 1904-1910.

[23] Whenham, R.J. 1975. The use of synthetic (+,-)- s-1-propyl-cysteine sulphoxide and of allinase preparations in studies of flavour changes resulting from processing of onion (Allium cepa I). J. Sci. Food Agric. 26, 1333-1346.

[24] Kubec, R, Svobodavá, M., Velisek, J. 2000. Distribution of S-Alk(en)ylcysteine Sulfoxides in Some Allium Species. Identification of a New Flavor Precursor: S-Ethylcysteine Sulfoxide (Ethiin). J. Agric. Food Chem J. Agric. Food Chem. 2000, 48, 428-433. 
Table1. Gas chromatography

Column temperature, $50-200{ }^{\circ} \mathrm{C}$

\section{Equipment and instructions for optimum analyses}

Temperature, $2^{\circ} \mathrm{C} \min ^{-1}, 0-20 \mathrm{~min}$

$4^{\circ} \mathrm{C}$ after $20 \mathrm{~min}$

$200{ }^{\circ} \mathrm{C}$ constant $15 \mathrm{~min}$

Injector temperature, $250{ }^{\circ} \mathrm{C}$

Detector " , $300{ }^{\circ} \mathrm{C}$

GLC: $\mathrm{y}=0.059+1,826 \mathrm{x} . \mathrm{r}=1.00$

Frozen onion $-25^{\circ} \mathrm{C} y=57-0.24 x . R=0.97$

Temp. $\log _{10}\left(\mathrm{t}_{1}-{ }_{0}\right)=1.84-0.074 x . \mathrm{R}=1.00$
Attenuator, $2^{\wedge} 7$

Detector signal, b-a

Slope gradient, $0.1,0-25 \mathrm{~min}$

1 after $15 \mathrm{~min}$

Carrier gas, $7 \mathrm{ml} \mathrm{N} \mathrm{min}^{-1}$

Base line 15, 18, 29, 37, 48, 50, 57 min

Abs. $\mathrm{y}=0.74+476.2 \mathrm{x}, \mathrm{R}=1.00$

Firmness $\mathrm{y}=419-6.29 \mathrm{x} \mathrm{R}=0.964$

Temp 1, $94{ }^{\circ} \mathrm{C}$ glass jars $760 \mathrm{ml}, \mathrm{f}=13.5$

Table2. Effects of storage time on the content of pyruvic acid at $25^{\circ} \mathrm{C}$ (cv. Hydro)

\begin{tabular}{cccccc}
\hline Storage time, days & & $\mathbf{0}$ & $\mathbf{7}$ & $\mathbf{6 0}$ & $\mathbf{9 0}$ \\
Gas chromatography & $\mathrm{mg} 100 \mathrm{~g}^{-1}$ & $73 \mathrm{aq}$ & $55 \mathrm{bp}$ & $43 \mathrm{cp}$ & $32 \mathrm{dp}$ \\
Spectrometry & $\cdots$ & $82 \mathrm{ap}$ & $54 \mathrm{bp}$ & $46 \mathrm{cp}$ & $37 \mathrm{~d}$ \\
\hline
\end{tabular}

Table 3. Pyrowic contents in nineteen cultivars stored 10 months at $-25^{\circ} \mathrm{C}$.

\begin{tabular}{|c|c|c|c|c|c|c|c|c|c|c|c|c|c|}
\hline \multicolumn{14}{|c|}{ Cultivar names and concentration of pyruvic acid } \\
\hline Sturon & $23 \mathrm{i}$ & Robot & $23 \mathrm{j}$ & Sturon & $23 \mathrm{j}$ & Zirius & $23 \mathrm{j}$ & Diskos & $18 \mathrm{k}$ & Tarzan & 111 & & \\
\hline
\end{tabular}

Table 4. Effects of blanching temperature and time on drained weight, firmness and colour.

\begin{tabular}{|c|c|c|c|c|c|c|c|c|c|c|c|c|}
\hline \multirow{2}{*}{$\begin{array}{l}{ }^{\circ} \mathrm{C} / \\
\text { Min }\end{array}$} & \multicolumn{4}{|c|}{ Drained weight, $\mathrm{g}$} & \multicolumn{4}{|c|}{ Firmness, kg } & \multicolumn{4}{|c|}{ Yellow/green } \\
\hline & 0 & 1 & 2 & 4 & 0 & 1 & 2 & 4 & 0 & 1 & 2 & 4 \\
\hline 70 & 152ap & $148 b p$ & $146 \mathrm{br}$ & 153ap & $448 \mathrm{cr}$ & 500ap & 500ap & $436 \mathrm{cp}$ & $\mathrm{rb}$ & $\mathrm{rb}$ & $\mathrm{rb}$ & $\mathrm{rb}$ \\
\hline 75 & 157ap & $151 \mathrm{bq}$ & $150 \mathrm{bq}$ & $144 \mathrm{cq}$ & $409 \mathrm{dt}$ & 500ap & $483 \mathrm{bq}$ & $432 \mathrm{cp}$ & “ & “ & “" & 6 \\
\hline 80 & 153ap & $144 \mathrm{bq}$ & 155ap & 152ap & $432 \mathrm{cs}$ & $369 \mathrm{bq}$ & $307 \mathrm{cr}$ & $214 \mathrm{dq}$ & “ & “ & $\mathrm{y} / \mathrm{g}$ & $\mathrm{y} / \mathrm{g}$ \\
\hline 85 & 152ap & 156ap & 157ap & 153ap & $475 \mathrm{bq}$ & $198 \mathrm{cr}$ & $181 \mathrm{ds}$ & $181 \mathrm{cr}$ & “ & $\mathrm{y} / \mathrm{g}$ & $\mathrm{y} / \mathrm{g}$ & $\mathrm{y} / \mathrm{g}$ \\
\hline 90 & 152ap & 155ap & 155ap & $150 \mathrm{bq}$ & 500ap & $198 \mathrm{cr}$ & 134et & $95 \mathrm{ds}$ & “ & $\mathrm{y} / \mathrm{g}$ & $\mathrm{y} / \mathrm{g}$ & $\mathrm{y} / \mathrm{g}$ \\
\hline
\end{tabular}

( $r b=$ red brown, $y=$ yellow/green).

Table 5. Effects of blanching for 0 and 1 min by pasteurization for $0,5,10,15$ and 25 min at $85^{\circ} \mathrm{C}$ on firmnesss and greenness of pickled onion produced using onions from the two cultivars 'Hygro' and 'Hyduro'.

\begin{tabular}{llllllllllll}
\hline \multicolumn{2}{l}{ Blanching } & \multicolumn{2}{l}{ Firmness, kg } & \multicolumn{2}{l}{ Greenness, a } & \multicolumn{2}{l}{ Blanching } & \multicolumn{2}{l}{ Firmness, kg } & \multicolumn{2}{l}{ Greenness, a } \\
Min & Min & Hygro & Hyduro & Hygro & Hyduro & Min & Min & Hygro & Hyduro & Hygro & Hdoro \\
0 & 0 & $438 \mathrm{ap}$ & $371 \mathrm{a}$ & $-0.3 \mathrm{a}$ & $-2,1 \mathrm{a}$ & 1 & 0 & $354 \mathrm{a}$ & $303 \mathrm{~b}$ & $-3,7 \mathrm{a}$ & $-5,6 \mathrm{a}$ \\
0 & 5 & $418 \mathrm{a}$ & $304 \mathrm{~b}$ & $-2.1 \mathrm{~b}$ & $-5.0 \mathrm{~b}$ & 1 & 5 & $317 \mathrm{~b}$ & $286 \mathrm{c}$ & $-3.5 \mathrm{a}$ & $-6.7 \mathrm{~b}$ \\
0 & 10 & $253 \mathrm{a}$ & $226 \mathrm{c}$ & $-6.3 \mathrm{c}$ & $-5.1 \mathrm{~d}$ & 1 & 10 & $205 \mathrm{~d}$ & $184 \mathrm{e}$ & $-9.5 \mathrm{~b}$ & $-7.9 \mathrm{c}$ \\
0 & 15 & $259 \mathrm{~b}$ & $221 \mathrm{c}$ & $-6.2 \mathrm{c}$ & $-6.3 \mathrm{c}$ & 1 & 10 & $158 \mathrm{c}$ & $173 \mathrm{c}$ & $-9.6 \mathrm{~b}$ & $-7.7 \mathrm{c}$ \\
0 & 25 & $303 \mathrm{a}$ & $241 \mathrm{~b}$ & $-5.1 \mathrm{~d}$ & $-8.0 \mathrm{e}$ & 1 & 25 & $110 \mathrm{e}$ & $101 \mathrm{e}$ & $-8.8 \mathrm{c}$ & $-7.9 \mathrm{c}$ \\
\multicolumn{2}{ll}{ Average } & $334 \mathrm{a}$ & $273 \mathrm{~b}$ & $-4.0 \mathrm{a}$ & $-5.3 \mathrm{~b}$ & Average & $229 \mathrm{a}$ & $209 \mathrm{~b}$ & -7.0 & -7.45 \\
\hline
\end{tabular}

Table 6. Firmness and yellow/greenness without blanching.

\begin{tabular}{|c|c|c|c|c|c|c|c|c|c|c|c|c|c|c|c|c|}
\hline & FirmI & & & & & & & & Yello & /greel & ess (b & & & & & \\
\hline & Hygro & & & & Hydo & & & & Hygr & & & & Hydu & & & \\
\hline${ }^{\circ} \mathrm{C}$ & 0 & 1 & 2 & 4 & 0 & 1 & 2 & 4 & 0 & 1 & 2 & 4 & 0 & 1 & 2 & 4 \\
\hline 70 & $393 c$ & $465 b$ & $471 \mathrm{a}$ & $471 a$ & $427 d$ & $472 c$ & $500 \mathrm{a}$ & $483 b$ & $2.2 \mathrm{a}$ & $1.1 \mathrm{c}$ & $1.4 \mathrm{~b}$ & $1.6 \mathrm{~b}$ & $2.7 \mathrm{a}$ & $1.9 \mathrm{~b}$ & $2.1 \mathrm{~b}$ & $1.9 \mathrm{~b}$ \\
\hline 75 & $395 b$ & $443 a$ & $451 \mathrm{a}$ & $394 b$ & $375 c$ & $423 b$ & 441a & $369 c$ & $2.3 \mathrm{a}$ & $1.8 \mathrm{~b}$ & $1.8 \mathrm{~b}$ & $1.5 \mathrm{c}$ & $3.5 \mathrm{a}$ & $2.1 \mathrm{~b}$ & $0.4 \mathrm{c}$ & $0.1 \mathrm{c}$ \\
\hline 80 & $394 b$ & $407 a$ & $354 \mathrm{c}$ & $293 d$ & $371 \mathrm{a}$ & $429 b$ & $342 \mathrm{c}$ & $281 \mathrm{~d}$ & $2.1 \mathrm{a}$ & - & - & - & - & - & - & - \\
\hline & & & & & & & & & & $2.6 \mathrm{~b}$ & $3.4 \mathrm{c}$ & $3.8 \mathrm{~d}$ & $0.9 \mathrm{a}$ & $4.8 \mathrm{~b}$ & $4.3 \mathrm{~b}$ & $6.9 c$ \\
\hline 90 & $394 d$ & $438 \mathrm{a}$ & 425 & $386 \mathrm{c}$ & 391 & $536 a$ & $428 b$ & $378 \mathrm{c}$ & 2.2 & 0.1 & 0.1 & -0.7 & 2.4 & -0.8 & -0.6 & -1.6 \\
\hline
\end{tabular}

Table 7. Effect of blanching time on drained weight and colour of pickled onions characteristics $(\mathrm{rb}=\mathrm{red}$ brown $(y=$ yellow).

\begin{tabular}{lllllllllll}
\hline Properties & \multicolumn{3}{c}{ Blanching time, 0 min } & \multicolumn{7}{c}{ Blanching time, 1 min } \\
Pasteurization, min & 0 & 5 & 10 & 15 & 25 & 0 & 5 & 10 & 15 & 25 \\
Drained weight, g & $154 \mathrm{~b}$ & $158 \mathrm{~b}$ & $156 \mathrm{~b}$ & $157 \mathrm{~b}$ & $167 \mathrm{a}$ & $150 \mathrm{~b}$ & $152 \mathrm{~b}$ & $153 \mathrm{~b}$ & $156 \mathrm{a}$ & $154 \mathrm{~b}$ \\
Firmness, kg & $453 \mathrm{a}$ & $389 \mathrm{~b}$ & $257 \mathrm{c}$ & $180 \mathrm{~d}$ & $159 \mathrm{e}$ & $309 \mathrm{~b}$ & $313 \mathrm{a}$ & $256 \mathrm{c}$ & $207 \mathrm{~d}$ & $178 \mathrm{e}$ \\
Colour & $\mathrm{rb}$ & $\mathrm{rb}$ & $\mathrm{y} / \mathrm{g}$ & $\mathrm{y} / \mathrm{g}$ & $\mathrm{y} / \mathrm{g}$ & $\mathrm{rb}$ & $\mathrm{y} / \mathrm{g}$ & $\mathrm{y} / \mathrm{g}$ & $\mathrm{y} / \mathrm{g}$ & $\mathrm{y} / \mathrm{g}$ \\
\hline
\end{tabular}


Industrial Processing of Pickled and Pasteurized Onion (Allium Cepa L.)

Table 8. Firmness and green-yellowness increased without blanching for 0 to 15 min.

\begin{tabular}{|c|c|c|c|c|c|c|c|c|c|c|c|}
\hline \multicolumn{2}{|c|}{ Blanching } & \multicolumn{2}{|c|}{ Firmness, kg } & \multicolumn{2}{|c|}{ Greenness, a } & \multicolumn{2}{|c|}{ Blanching } & \multicolumn{2}{|c|}{ Firmness, kg } & \multicolumn{2}{|c|}{ Greenness, a } \\
\hline${ }^{\circ} \mathrm{C}$ & Min & Hygro & Hyduro & Hygro & Hyduro & ${ }^{\circ} \mathrm{C}$ & Min & Hygro & Hyduro & Hydro & Hyduro \\
\hline 0 & 5 & $418 \mathrm{aq}$ & $304 \mathrm{bq}$ & $-2.1 \mathrm{aq}$ & $-5.0 \mathrm{bq}$ & 1 & 5 & $317 \mathrm{aq}$ & $286 \mathrm{bq}$ & $-3.5 a p$ & $-6.7 b q$ \\
\hline 0 & 15 & 255 as & $226 \mathrm{cs}$ & $-6.3 \mathrm{ar}$ & $-5.1 b q$ & 1 & 15 & 205as & $184 \mathrm{bs}$ & $-9.5 b q$ & - 8.0ar \\
\hline 0 & 25 & $303 \mathrm{ar}$ & $241 \mathrm{br}$ & $-5.1 \mathrm{as}$ & $-8.0 \mathrm{br}$ & 1 & 25 & 210as & $201 \mathrm{br}$ & $-8.8 \mathrm{r}$ & $-7.9 \mathrm{as}$ \\
\hline
\end{tabular}

Table 9. Firmness and yellow green colour of pickled onion.

\begin{tabular}{lllll}
\hline Temp & Hygro & Hyduro & Hygro & Hyduro \\
70 & $450 \mathrm{a}$ & $471 \mathrm{a}$ & $1.5 \mathrm{~b}$ & $1,8 \mathrm{a}$ \\
75 & $421 \mathrm{~b}$ & $402 \mathrm{~b}$ & $2,0 \mathrm{a}$ & $1,7 \mathrm{~b}$ \\
80 & $362 \mathrm{c}$ & $356 \mathrm{c}$ & $-2.0 \mathrm{a}$ & $-1,6 \mathrm{c}$ \\
85 & $282 \mathrm{c}$ & $241 \mathrm{~d}$ & $-4,3 \mathrm{~b}$ & $-3,4 \mathrm{~d}$ \\
90 & $219 \mathrm{~d}$ & $212 \mathrm{e}$ & $-5,3 \mathrm{c}$ & $-4,6 \mathrm{e}$ \\
\hline
\end{tabular}

Table 10. Effects of blanching on drained weight, firmness and colour of onion pickles.

\begin{tabular}{|c|c|c|c|c|}
\hline${ }^{\circ} \mathrm{C}$ & Min & Weight, g jar ${ }^{-1}$ & Firmness, kg & Colour \\
\hline 70 & 0 & $152 \mathrm{a}$ & $448 b$ & reddish \\
\hline “ & 1 & $148 b$ & $500 \mathrm{a}$ & “ \\
\hline “ & 2 & $146 b$ & $500 \mathrm{a}$ & “ \\
\hline “ & 4 & $153 a$ & $436 \mathrm{~b}$ & “ \\
\hline \multirow[t]{2}{*}{75} & 0 & $157 \mathrm{a}$ & $409 c$ & “ \\
\hline & 1 & $151 b$ & $500 \mathrm{a}$ & “ \\
\hline “" & 2 & $150 \mathrm{~b}$ & $483 a$ & “ \\
\hline “" & 4 & $144 \mathrm{c}$ & $432 b$ & “ \\
\hline 80 & 0 & $153 a$ & $432 \mathrm{a}$ & “" \\
\hline “ & 1 & $144 b$ & $369 b$ & “ \\
\hline “ & 2 & $155 \mathrm{c}$ & $307 c$ & green \\
\hline “ & 4 & $152 \mathrm{c}$ & $214 d$ & “ \\
\hline \multirow[t]{2}{*}{85} & 0 & $152 \mathrm{a}$ & $475 a$ & reddish \\
\hline & 1 & $156 \mathrm{a}$ & $198 b$ & green \\
\hline “ & 2 & $156 \mathrm{a}$ & $181 \mathrm{c}$ & “ \\
\hline “ & 4 & $157 \mathrm{a}$ & $181 \mathrm{c}$ & “ \\
\hline 90 & 0 & $153 a$ & $500 \mathrm{a}$ & reddish \\
\hline " & 0 & $152 \mathrm{a}$ & $198 b$ & green \\
\hline “" & 1 & $151 \mathrm{a}$ & $134 \mathrm{c}$ & $"$ \\
\hline “ & 2 & $155 \mathrm{a}$ & $95 \mathrm{~d}$ & “ \\
\hline “ & 4 & $150 \mathrm{a}$ & $95 \mathrm{~d}$ & “ \\
\hline
\end{tabular}

Table 11. Properties by processing of pickled onion with thermal diffusivity $\alpha$ and heat transfer $K$.

\begin{tabular}{lllllll}
\hline $\begin{array}{l}\text { Volume, } \\
\mathbf{c m}^{\mathbf{3}}\end{array}$ & Height, $\mathbf{c m}$ & Diameter, $\mathbf{c m}$ & $\mathbf{F}, \mathbf{m i n}$ & $\boldsymbol{\alpha}, \mathbf{c m}^{\mathbf{2}} \mathbf{~ m i n}^{-1}$ & $\mathbf{K ~ c a l , ~} \mathbf{c m}^{-1}, \mathbf{m i n}^{-1}$ & $\mathbf{M i n}, \mathbf{8 5}^{\mathbf{0}} \mathbf{C}$ \\
370 & $12.0 \mathrm{c}$ & $7.1 \mathrm{~d}$ & 12.2 & $0.358 \mathrm{e}$ & $0.33 \mathrm{~d}$ & $11.1 \mathrm{c}$ \\
380 & $8.1 \mathrm{a}$ & $9.2 \mathrm{c}$ & 12.6 & $0.431 \mathrm{~d}$ & $0.40 \mathrm{c}$ & $11.5 \mathrm{c}$ \\
580 & $11.6 \mathrm{~b}$ & $9.3 \mathrm{c}$ & 13.7 & $0.493 \mathrm{c}$ & $0.45 \mathrm{~b}$ & $12.5 \mathrm{~b}$ \\
720 & $14.6 \mathrm{~d}$ & $9.0 \mathrm{~b}$ & 13.4 & $0.517 \mathrm{~b}$ & $0.48 \mathrm{a}$ & $12.2 \mathrm{~b}$ \\
1100 & $17.9 \mathrm{e}$ & $9.8 \mathrm{a}$ & 15.5 & $0.547 \mathrm{a}$ & $0.50 \mathrm{a}$ & $14.2 \mathrm{a}$
\end{tabular}

Citation: K. Kaack " Industrial Processing of Pickled Pasteurized Onion(Allium Cepa L.)", International Journal of forestry and Horticulture (IJFH), vol. 3, no. 2, p. 11, 2017, http:// dx.doi.org /10.20431/24549487.0302005.

Copyright: (C) 2017 Authors. This is an open-access article distributed under the terms of the Creative Commons Attribution License, which permits unrestricted use, distribution, and reproduction in any medium, provided the original author and source are credited. 